UDC 666.97.003.16

\title{
VIBRATING TABLES WITH THE SPATIAL OSCILLATIONS OF THE MOVING FRAME TECHNOLOGICAL PROPERTIES FOR FORMING REINFORCED CONCRETE PRODUCTS
}

\author{
Nesterenko Mykola ${ }^{1 *}$, Nesterenko Mykola ${ }^{2}$, Orysenko Olexandr ${ }^{3}$, Sklyarenko Taras ${ }^{4}$, \\ ${ }^{1}$ Poltava National Technical Yuri Kondratyuk University https://orcid.org/0000-0002-8961-2147 \\ ${ }^{2}$ Poltava National Technical Yuri Kondratyuk University https://orcid.org/0000-0002-4073-1233 \\ ${ }^{3}$ Poltava National Technical Yuri Kondratyuk University https://orcid.org/0000-0003-3103-0096 \\ ${ }^{4}$ Poltava National Technical Yuri Kondratyuk University https://orcid.org/0000-0003-2052-6889 \\ *Corresponding author E-mail: nesterenkonikola@gmail.com
}

\begin{abstract}
A brief description of vibration tables with spatial oscillations of a moving frame and comparison of their technological possibilities depending on their constructive execution are given. The methodology for evaluating the technological and structural parameters of the vibration tables is also presented based on the use of a dimensionless complex parameter that enables to evaluate the consumer qualities of the vibrating tables, their technical level and competitiveness during the design and operation stage. The vibrating machines constructive designs schemes, their characteristics and the description of the scope of application are presented, which enables designers and manufacturers to orientate themselves in the variety of currently used vibration machines with spatial oscillations of the moving frame for the formation of the same type of reinforced concrete products.
\end{abstract}

Keywords: vibration table, vibration exciter, forming concrete reinforced products

\section{ТЕХНОЛОГІЧНІСТЬ ВІБРАЦІЙНИХ ПЛОЩАДОК 3 ПРОСТОРОВИМ РУХОМ РУХОМОЇ РАМИ ДЛЯ ФОРМУВАННЯ ЗАЛІЗОБЕТОННИХ ВИРОБІВ}

\author{
Нестеренко М.П. ${ }^{1 *}$, Нестеренко М.М. ${ }^{2}$, Орисенко О.В. ${ }^{3}$, Скляренко Т.O. ${ }^{4}$ \\ 1,2,3,4 Полтавський національний технічний університет імені Юрія Кондратюка \\ *Адреса для листування E-mail: E-mail: nesterenkonikola@gmail.com
}

\begin{abstract}
Наведено короткий опис вібраційних площадок з просторовими коливаннями рухомї рами та порівняння їх технологічних можливостей залежно від їх конструктивного виконання. На виробництві збірного залізобетону для ущільнення бетонних сумішей використовують віброплощадки різноманітних конструкцій, які значною мірою визначають технологічну ефективність обладнання і продуктивність підприємства. Широкого розповсюджені набули розроблені у різні роки КБ «Вібротехніка» ПолтНТУ вібраційні площадки 3 просторовим рухом робочого органа, які мають можливість якісного та продуктивного формування залізобетонних виробів усієї номенклатури. Існуючий дефіцит вібраційних машин і невизначеність у виборі пріоритетних напрямів їх розвитку створюють на виробництві значні труднощі щодо проектування чи технічного переоснащення формувальних постів підприємств збірного залізобетону. При проектуванні формувальних постів та виборі технологічного обладнання для ущільнення бетонної суміші при виготовленні залізобетонних виробів необхідна оцінка технологічних можливостей усіх різновидів віброплощадок з просторовими коливаннями рухомої рами. Також наведено їх короткий опис та порівняння технологіічних можливостей залежно від конструктивного виконання. Наведено методику оцінки технологічних і конструктивних параметрів віброплощадок, що грунтується на використанні безрозмірного комплексного параметра. Вона дозволяє як на стадії проектування, так і в процесі експлуатації оцінити споживчі якості віброплощадок, їхній технічний рівень і конкурентоспроможність. Аналіз наведених схем конструктивних виконань вібраційних машин, їх характеристик та опис сфери застосування дозволять проектувальникам та виробничникам орієнтуватися в різноманітті використовуваних сьогодні вібраційних машин для формування однотипних залізобетонних виробів.
\end{abstract}

Ключові слова: вібраційна площадка, віброзбуджувач, формування залізобетонних виробів. 


\section{Introduction}

The development of rural, including farms, involves intensive construction of housing and farm buildings that are cheap in price and have high quality. In addition, natural disasters that have occurred in Ukraine in recent years. have identified the need for the development of technology of high quality and fast construction in difficult conditions. Emergency situations require prompt and immediate construction in unsuitable conditions for its conduction. Therefore, in modern construction, concrete products are still in demand. At the production of prefabricated reinforced concrete for consolidating concrete mixtures, vibration tables of various structures are used. The researches described in $[1-7]$ the equipment technological efficiency of equipment and enterprise productivity has been determibed. The industry of Ukraine and CIS countries vibroforming equipment is not serially produced, and enterprises are forced to replenish it independently in conditions of metal and component parts scarcity. Existing deficit of vibration machines and uncertainty in the choice of priority directions of their development create significant difficulties in the production of designing or technical re-equipment of forming posts of prefabricated reinforced concrete enterprises.

\section{Review of research sources and publications}

The variety of such equipment is used in the production $[1-7]$, which is explained by various scientific concepts of vibration technology and concrete mixtures consolidation, which have repeatedly changed, although the requirements for the quality of prefabricated reinforced concrete products practically remained unchanged. Existing deficit of vibration machines and uncertainty in their development priority directions choice create considerable difficulties in the production of technical re-equipment of prefabricated reinforced concrete enterprises forming posts technical re-equipment production.

The design bureau «Vibrotechnics» of the Poltava National Technical Yuri Kondratyuk University has developed a uniform series of low-frequency $(24 \mathrm{~Hz})$ vibrating tables with spatial oscillations of a moving frame (Figure 1) [7] which contains nine sizes of loadcarrying capacity from 10 to $30 \mathrm{t}$ for the production of products in the plan of $1.5 \times 6$ to $3 \times 12 \mathrm{~m}$. Vibration tables are extremely simple construction with a minimum of components, they are economical for power consumption, reliable in operation and are used both in closed production facilities and as in open landfills of reinforced concrete. By joining on short edges of two identical vibration tables, their maximum load-carrying capacity can be increased to $60 \mathrm{t}$, and the dimensions of the product - up to $3 \times 24 \mathrm{~m}$. Such vibration tables were produced in small quantities for construction companies.

\section{Definition of unsolved aspects of the problem}

When designing forming posts and the choice of technological equipment for consolidating the concrete mixtures in the manufacture of reinforced concrete products, the technological capabilities assessment of all varieties of vibration tables with moving frame spatial oscillations is required.

\section{Problem statement}

The purpose of this work is to evaluate the technological capabilities of all varieties of vibration tables with moving frame spatial oscillations for consolidating the concrete mixture.

\section{Basic material and results}

Vibration tables with spatial oscillations of a moving frame are vibratory machines where the unbalanced vibration exciter of circular oscillations are driven by electric motors installed on the basement, with the help of a belt transmission (Fig. 1 and 2) [7]. In such structures of vibration tables there are no gears.

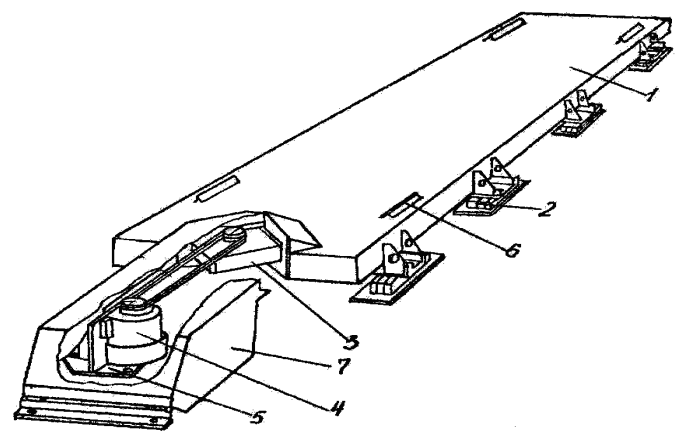

Figure 1 - Scheme vibration table with the end position of the vibration exciter:

1 - moving frame; 2 - elastic rubber-metal support; 3 - vertical shaft vibration exciter; 4 - electric motor;

5 - frame electric motor; 6 - stop wedge transverse;

$$
7 \text { - cover }
$$

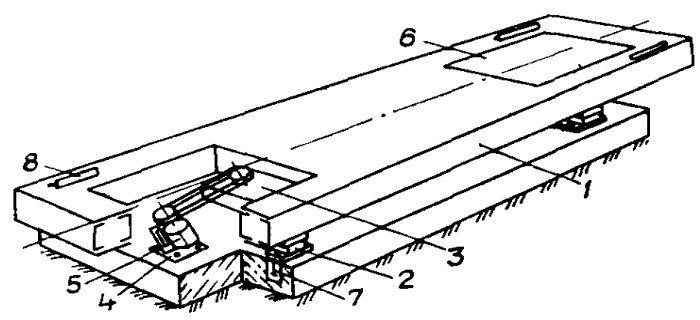

Figure 2 - Scheme vibration table with two inclined vibration exciters:

1 - moving frame; 2 - elastic rubber-metal support; 3 - vibration exciter; 4 - frame electric motor

5 - electric motor; 6 - cover; 7 - bolt basement; 8 - stop wedge transverse

Initial data when designing vibration tables for the formation of reinforced concrete products is the type of product, its mass and overall dimensions. The load-carrying capacity of the vibration table $\mathrm{Q}$ is determined, which is defined as the total mass of the form, the vibration equipment and technological equipment. The frame overall dimensions of the vibration table $L_{X}$ and $L_{Y}$ are calculated considering the overall dimensions in 
the form of the plan, with the need to further consideration the possibility of mounting the stop wedge transverses.

Spatial oscillations of moving frames provide sufficient technological efficiency at accelerations in the horizontal plane a range as $a_{h}=(1,5 \ldots 2,5) \mathrm{g}$, and at the level of sound pressure do not exceed the sanitary-hygienic norms and do not require additional measures.

When forming products of various sizes from mixtures with slump a range as $1 \ldots 4 \mathrm{~cm}$, a form freely set on vibration moving frame and restrict from slipping through stop wedge transverses. When using concrete mixtures with the stiffness a range as $11 \ldots 20 \mathrm{~s}$ requires the jamming of forms on a moving frame, vibration tables two or three pairs of hard wedge stops. In addition to the carrying capacity, the size of the moving frame and the intensity of vibration, the technological capabilities of these vibration tables largely depend on the variants of the vibration exciters location on the moving frame vibration table with vertical or inclined unbalanced shafts relative to the vertical axis passing through the center of the oscillatory system masses. The advantage of using inclined vibration exciters is to increase the technological efficiency of low-frequency vibration tables by increasing the vertical component of the amplitude vibrations of the moving frame, that is important for the qualitative consolidating of stiff concrete mixtures.

Considered technological capabilities of vibration tables with spatial oscillations of the moving frame for the formation of the same type of reinforced concrete carried out according to the design schemes presented in Figure 3. a)

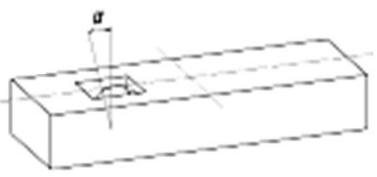

b)

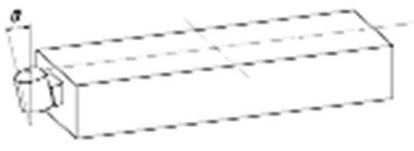

c)

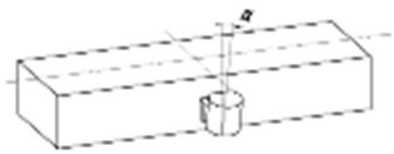

d)

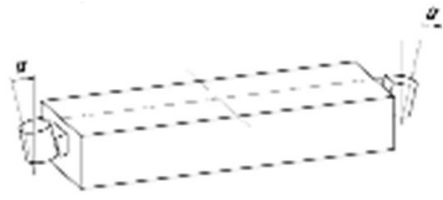

e)

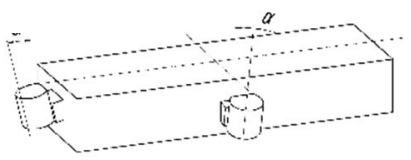

Figure 3 - Generalized technical scheme vibration tables with variants of the location of vibration exciters on the moving frame

When choosing vibration tables for the formation of reinforced concrete products it is convenient to use generalized technical characteristics of vibration tables with spatial oscillations of the working organ, given in Table 1.

Table 1 - Generalized technical characteristics of vibration tables

\begin{tabular}{|c|c|c|c|c|c|c|}
\hline \multirow{2}{*}{\multicolumn{2}{|c|}{ Parameter }} & \multicolumn{5}{|c|}{ Constructive execution (Figure 2) } \\
\hline & & $\mathrm{a}$ & $\mathrm{b}$ & $\mathrm{c}$ & $\mathrm{d}$ & $\mathrm{e}$ \\
\hline \multicolumn{2}{|c|}{ Load-carrying capacity, $\mathrm{t}$} & $0,2 \ldots 25$ & $10 \ldots 25$ & $0,4 \ldots 20$ & $12 \ldots 100$ & $2 \ldots .80$ \\
\hline \multicolumn{2}{|c|}{$\begin{array}{l}\text { Dimensions in plan of } \\
\text { products to be formed, m: } \\
\text { - width } \\
\text { - length }\end{array}$} & $\begin{array}{c}0,8 \ldots 3 \\
1,5 \ldots 12\end{array}$ & $\begin{array}{c}1 \ldots 3 \\
3 \ldots 14\end{array}$ & $\begin{array}{c}1 \ldots 2 \\
2 \ldots 12\end{array}$ & $\begin{array}{l}1,5 \ldots 3- \\
3 \ldots 15\end{array}$ & $\begin{array}{l}2 \ldots 12 \\
2 \ldots 12\end{array}$ \\
\hline \multicolumn{2}{|c|}{$\begin{array}{l}\text { Power driven } \\
\text { electric motors, } \mathrm{kW}\end{array}$} & $0,55-22$ & $11-22$ & $0,75-22$ & $(11 \ldots 30) \times 2$ & $(1,1 \ldots 30) \times 2$ \\
\hline \multicolumn{2}{|c|}{ Weight of vibration table, $\mathrm{t}$} & $0,3-8$ & $5-11$ & $0,4-10$ & $5,6-16$ & $0,6-14$ \\
\hline \multirow{2}{*}{$\begin{array}{l}\text { Concrete } \\
\text { mixture }\end{array}$} & slump, cm & $5 \ldots 10$ & $1 \ldots 4$ & $1 \ldots 4$ & - & $1 \ldots 4$ \\
\hline & stiffnes, s & - & - & - & $11 \ldots 20$ & - \\
\hline \multicolumn{2}{|c|}{$\begin{array}{l}\text { Application for the manu- } \\
\text { facture of reinforced con- } \\
\text { crete products }\end{array}$} & $\begin{array}{l}\text { On aggregate- } \\
\text { current and } \\
\text { conveyor } \\
\text { lines }\end{array}$ & \multicolumn{2}{|c|}{$\begin{array}{l}\text { On aggregate-current lines and } \\
\text { at outdoor landfills }\end{array}$} & $\begin{array}{l}\text { On aggregate- } \\
\text { current and } \\
\text { conveyor } \\
\text { lines }\end{array}$ & $\begin{array}{l}\text { At outdoor } \\
\text { landfills }\end{array}$ \\
\hline \multicolumn{2}{|c|}{ Types of formed products } & $\begin{array}{l}\text { Ribbed plates, } \\
\text { wall linear } \\
\text { and selective } \\
\text { elements in } \\
\text { cassette forms }\end{array}$ & $\begin{array}{l}\text { Ribbed plates, } \\
\text { pails }\end{array}$ & $\begin{array}{l}\text { Plates of } \\
\text { overlappings } \\
\text { are linear and } \\
\text { spatial ele- } \\
\text { ments }\end{array}$ & $\begin{array}{l}\text { Many hollow } \\
\text { Plates of } \\
\text { overlappings, } \\
\text { electric sup- } \\
\text { ports }\end{array}$ & $\begin{array}{l}\text { Plates of } \\
\text { overlappings, } \\
\text { spatial ele- } \\
\text { ments, hydro- } \\
\text { technical } \\
\text { blocks }\end{array}$ \\
\hline
\end{tabular}


Analysis of constructive performances of vibration tables with spatial oscillations of a working frame:

a) with an in-depth location of the vibration exciter in the window of the moving frame, in other equal conditions, has the simplest construction and minimal dimensions in plans of the form relative size. The components of the vibrational displacements amplitudes on three coordinate axes are evenly distributed along the perimeter of the moving frame. The reduced values of the vertical components of the vibro displacement in the central part of the moving frame in the case of the installation of a vertical shaft vibration exciter may be aligned due to the tilting of the rotation axis of the unbalanced shaft a range as $5 \ldots 15^{\circ}$ from the vertical.

b) with the end face vibration exciter, like all the following, increases the dimensions of the vibration table relative to the size of the forms and requires the installation of protective covers over the vibration drive. This location of the vibration exciter is most convenient in terms of maintenance and repair. In this constructive version, along the length of the moving frame, two zones of reduced intensity of vibration appear: in the central part, due to the small vertical components of the amplitudes of the vibrational displacements, and in the zone distant from the vibrational platform at a distance equal to $1 / 4 \ldots 1 / 3$ of the moving frame length, where the small transverse components of these amplitudes exist. Inevitable flexible oscillations of the form pallet elements and its sides, smoothes the display of the amplitudes calculated lower values of vibro displacement in these zones, and their presence has little effect on the quality of concrete mixtures compaction with slump a range as $3 \ldots 5 \mathrm{~cm}$ and more, however, this technological feature should be foreseen in quality control and commodity type of long-range products in the specified «risk areas». The application of the first portions of the concrete mixture to these places of the form for obtaining a long product promotes the uniformity of sealing the mixture throughout its length. In general, the good technological feasibility of this constructive option was determined by its recognition by manufacturers and relatively widespread at outdoor landfills of the year-round operation;

c) with a vibration exciter, mounted on the long side of the moving frame of the vibration table, provides more even distribution of the transverse amplitudes of vibrational displacements. Their calculated «lowered zone» extends beyond the boundary of the moving frame, but the vertical components in its central part retain reduced values, which is a definite condition for its application for the formation of spatial elements of different height with a central cavity (pressure elements of pipes of any diameter, rings for wells, elements of elevators, block rooms, etc.). The unbalanced shaft rotation slope enables to eliminate the «lowered zone» of the amplitudes vertical components of the vibrational displacements complicating the arrangement of the vibration drive;

d) with two independent vibration exciters installed on the ends or in the windows of the moving frame. When working with vibration exciters, there are forces of circular action that cause spatial oscillations of the moving frame and are transmitted through the form to the concrete mixture. The oscillating system is designed so that the vibrational displacement of the moving frame points has the character of the bits, which period varies from 1 to $8 \mathrm{~s}$ for different types of sizes. When intervals corresponding to the antiphase rotation of unbalances, when vibration exciters for a short time enter the self-synchronization mode, the moving frame makes oscillations predominantly in transverse and vertical planes. This mode of vibration enables to form concrete mixtures efficiently that increases the technological efficiency of the vibration table. The disadvantage of this design option is the complexity of the design and the increase in the number of component parts by doubled;

e) with two independent vibration exciters installed on the adjacent sides of the movable frame, considering the self-synchronization mode. Such a constructive implementation provides for an increase in mainly horizontal oscillations along its diagonal and to a lesser extent causes other components of the amplitudes of vibrational displacements. Such a technical solution is effective for the formation of spatial elements of mass and height with a square or rectangular cross-section. Vertical formwork forms perceive simultaneously the same dynamic pulses along the direction, and, accordingly, all four vertical walls of a spatial product receive the same degree of consolidation. Formation of reinforced concrete products with a mass of less than half of the calculated load-carrying capacity can be carried out by switching on one vibration exciter. The inclination of the vibration exciters increases the vertical component of the vibrations in the formation of large-sized products, with dimensions in the plan of $6 \times 6,9 \times 9$, or $12 \times 12 \mathrm{~m}$. On such a vibration tables installed on an open landfill near the construction site, in the area of the crane, the large-sized fragments of the assembly monolithic constructions. It enables to implement progressive volumetric planning decisions and to shorten the construction period.

It is convenient to create stationary vibration forms for the production of large-sized and spatial reinforced concrete products, to carry out modernization of cassette and other installations on the basis of unified nodes of vibration tables in accordance with the above considered variants of constructive execution of vibration tables.

The unified vibration kits VK-1, VK-2, VK-3 (Table 2) enable to organize the production of largesize reinforced concrete structures in improved stationary vibration forms of different configuration and mass, both in closed production facilities and in oupan landfills in the short term and with minimal cost,. The fastening nodes of vibration exciter and elastic supports are modernized to a concrete form individually.

It is also easy to create small vibration tables with a load-carrying capacity from 0,2 to $2,5 \mathrm{t}$ with the use of one or two suspended universal vibration exciters for the formation of common small-sized reinforced concrete products in single or cassette forms. 
For example, the vibration table PL-2,5 with two hinged vibration exciters IV-105 with a frequency of 24 $\mathrm{Hz}$ and a total power of $2.2 \mathrm{~kW}$ has a carrying capacity of $2.5 \mathrm{t}$ and enables to form products with dimensions in the plan of $1.6 \times 7.2 \mathrm{~m}$. The feasibility of manufacturing small vibration tables is confirmed by many foreign firms in Italy, France, Japan. In the CIS countries, such vibration tables are not manufactured.

\section{Table 2 - Generalized technical characteristics of unified vibration kits}

\begin{tabular}{|l|c|c|c|}
\hline \multirow{2}{*}{\multicolumn{1}{|c|}{ Parameter }} & \multicolumn{3}{|c|}{ Vibration kit } \\
\cline { 2 - 4 } & VK-1 & VK-2 & VK-3 \\
\hline $\begin{array}{l}\text { Load-carrying capacity } \\
\text { (mass of form with } \\
\text { a concrete mixture), } \mathrm{t}\end{array}$ & $5-12$ & $15-25$ & $30-55$ \\
\hline $\begin{array}{l}\text { Frequency of oscilla- } \\
\text { tions of a moving } \\
\text { frame, Hz }\end{array}$ & \multicolumn{3}{|c|}{$24-30$} \\
\hline $\begin{array}{l}\text { Vibration drive } \\
\text { power, kW }\end{array}$ & 7 & 11 & 22 \\
\hline $\begin{array}{l}\text { Weight of units of } \\
\text { vibration kit } \\
\text { (depending on the num- } \\
\text { ber of supports), kg }\end{array}$ & $700-$ & $870-$ & $1590-$ \\
1190 & 2060 \\
\hline
\end{tabular}

Technological and operational parameters of vibration tables [ $8-10]$ are also easy to evaluate according to the calculation method proposed by us [10]. The method of calculation, based on the use of a dimensionless complex parameter, enables both at the design stage and during the process of exploitation to evaluate the consumer quality of vibration tables, their technical level and competitiveness by the following formula

$$
I=\frac{\sqrt{\left(k a_{h} f g \omega\right)^{2}+a_{v}^{2} \omega^{3}}}{N / Q} \cdot \frac{Q^{2}}{M_{v} M_{b}} \cdot \frac{115-L}{L} \cdot \frac{180}{t},
$$

where $k$-coefficient considering the influence of the tangent component of the amplitude of the oscillations of the concrete mixture, is taken within the range as $0.2 \ldots 0.4$ depending on the stiffness of the concrete mixture;

$f$ - coefficient considering the friction of the concrete mixture on the pallet of the form $(f=0.10 \ldots 0.12)$;

$g$ - acceleration of free fall;

$a_{h}$ and $a_{v}$ - amplitude of the horizontal and vertical vibrations of the moving frame respectively;

$\omega-$ angular frequency of oscillations, $\mathrm{s}^{-1}$;

$N$ - installed power of the vibration drive, $\mathrm{kW}$;

$Q$ - maximum load-carrying capacity of the vibration table, $\mathrm{t}$;

$M_{v}$ - weight of the vibration table, t;

$M_{b}$ - weight of basement vibration table, t;

$L-$ actual equivalent noise level at the workplace, dBA; $t$ - the total duration of the vibration table inclusions during the cycle of products formation of the same type, $s$.

The complex parameter includes four factors, which respectively reflect: the efficiency of energy consumption, the material content of the vibration table, considering the weight of the basement, relative sanitary and hygienic conditions of work on the noise level at the workplace, technological efficiency of the vibrating machine. The higher the dimensionless complex parameter $I$, the more perfect the vibration table. In tab. 3 there are shown the results of the comparison with the proposed dimensionless complex parameter of the operational qualities of the most common in the production of four vibration tables for the formation of the same type of products with a size of $3.0 \times 6.0 \mathrm{~m}$. In this case, the amplitude of the vibro displacements indicated in Table 3 corresponds to the regimes adopted on practice that ensures the performance of these vibrating machines and the proper quality of consolidating the concrete mixture. The dimensionless complexity of the vibrating table VPG$2 \mathrm{M}-07$ is higher in comparison with vibrating table areas: SMG-538A in 1,66 times; SMG-200G is 7.16 times, SMG-773 is 1.33 times.

Table 3 - Comparison of technological and operational qualities the most common vibration tables with the help of dimensionless complex parameter

\begin{tabular}{|l|c|c|c|c|}
\hline \multirow{2}{*}{ Parameter } & \multicolumn{4}{c|}{ Values of parameters for vibration tables } \\
\cline { 2 - 5 } & SMG -538A & SMG -200G & SMG -773 & VPG-2M-07 \\
\hline Load-carrying capacity, t & 18 & 15 & 20 & 16 \\
\hline Angular frequency of oscillations, s ${ }^{-1}$ & 152 & 300 & 152 & 188 \\
\hline Actual equivalent noise level, dBa & 80 & 100 & 85 & 80 \\
\hline $\begin{array}{l}\text { Amplitude of vibrations of the working body, } \mathrm{m}: \\
\text { - horizontally } \\
\text { - vertically }\end{array}$ & - & - & - & $0.60 \cdot 10^{-3}$ \\
\hline Installed power of the vibration drive, $\mathrm{kW}$ & $0.75 \cdot 10^{-3}$ & $0.35 \cdot 10^{-3}$ & $1.0 \cdot 10^{-3}$ & $0.28 \cdot 10^{-3}$ \\
\hline Basement mass, t & 44 & 88 & 50 & 37 \\
\hline Total vibration drive activation time, $\mathrm{s}$ & 75 & 120 & 90 & 48 \\
\hline Dimensionless complex parameter & 180 & 90 & 180 & 180 \\
\hline
\end{tabular}




\section{Conclusions}

1. The main property of vibration tables with spatial oscilations of a moving frame is the possibility of the entire nomenclature products qualitative and productive formation according to the planned volume at a separate factory of reinforced concrete products, which facilitates their manufacturing, maintenance and ongoing repair of forming equipment.

2. The given schemes of constructive variants of execution of vibration tables with spatial oscilations of a moving frame enable designers and manufacturers to be more easily guided in the variety of currently used vibration machines for the formation of the same type of reinforced concrete products.

3. The method for evaluating the performance of vibration tables with the help of a dimensionless complex parameter enabes both at the design stage and during the process of exploitation to evaluate the consumer qualities of vibration machines of different design, to determine their technical level and competitiveness on the set of basic technical parameters.

\section{References}

1. Banfill, P.F.G., Teixeira M.A.O.M. \& Craik, R.J.M. (2011). Rheology and vibration of fresh concrete: Predicting the radius of action of poker vibrators from wave propagation.

Cement and Concrete Research, 41(9), 932-941.

https://doi.org/10.1016/j.cemconres.2011.04.011

2. Juradian, S., Baloevic, G. \& Harapin, A. (2014). Impact of vibrations on the final characteristics of normal and selfcompacting concrete. Mat. Res. [online], 17(1), 178-185.

http://dx.doi.org/10.1590/S1516-14392013005000201.

3. Nazarenko, I., Ruchynskyi, M. \& Delembovskyi, M. (2018). The basic parameters of vibration settings for sealing horizontal surfaces International Journal of Engineering \& Technology (UAE), 7(3.2), 255-259.

http://dx.doi.org/10.14419/ijet.v7i3.2.14415.

4. Nesterenko, M., Nazarenko, I. \& Molchanov, P. (2018) Cassette installation with active working body in the separating partition. International Journal of Engineering \& Technology (UAE), 7(3.2), 265-268.

http://dx.doi.org/10.14419/ijet.v7i3.2.14417

5. Nesterenko, M., Maslov, A. \& Salenko, J. (2018). Investigation of vibration machine interaction with compacted concrete mixture. International Journal of Engineering \& Technology (UAE), 7(3.2), 260-264.

http://dx.doi.org/10.14419/ijet.v7i3.2.14416.

6. Shigeyuki, D., Goryozono, Y. \& Hashimoto, S. (2012). Study on consolidation of concrete with vibration. Physics Procedia, 25, 325-332.

https://doi.org/10.1016/j.phpro.2012.03.091

7. Нестеренко, М.П. (2017). Прогресивний розвиток вібраційних установок 3 просторовими коливаннями для формування залізобетонних виробів. Збірник наукових прачь. Серія: Галузеве машинобудування, будівництво, 2(44), 16-23.

8. Свідерський, А.Т., Делембовський, М.М. (2010). Критерії оцінки якості віброплощадок. Техніка будівництва, 24, 24-27.

9. Сівко, В.Й., Кузьмінець, М.П. (2012). Оцінка впливу робочого середовища на режими коливань вібраційних машин. Теорія і практика будівництва, 10, 3-5.

10. Нестеренко, М.П., Білецький, В.С., Семко, О.В. (2017). Оцінка конструктивно-технологічних параметрів та експлуатаційних якостей вібраційних машин для формування залізобетонних виробів. Збірник наукових пращь. Серія: Галузеве машинобудування, будівниитвво, 1(43), 231-237.

11. Назаренко, I.I., Нестеренко, М.П. (2015). Методика досліджень загальної динамічної моделі «технологічна машина для будівельної індустрії - оброблюване середовище». Техніка будівництва, 34, 4-11.
1. Banfill, P.F.G., Teixeira M.A.O.M. \& Craik, R.J.M. (2011). Rheology and vibration of fresh concrete: Predicting the radius of action of poker vibrators from wave propagation. Cement and Concrete Research, 41(9), 932-941.

https://doi.org/10.1016/j.cemconres.2011.04.011

2. Juradian, S., Baloevic, G. \& Harapin, A. (2014). Impact of vibrations on the final characteristics of normal and selfcompacting concrete. Mat. Res. [online], 17(1), 178-185.

http://dx.doi.org/10.1590/S1516-14392013005000201.

3. Nazarenko, I., Ruchynskyi, M. \& Delembovskyi, M. (2018). The basic parameters of vibration settings for sealing horizontal surfaces International Journal of Engineering \& Technology (UAE), 7(3.2), 255-259.

http://dx.doi.org/10.14419/ijet.v7i3.2.14415.

4. Nesterenko, M., Nazarenko, I. \& Molchanov, P. (2018). Cassette installation with active working body in the separating partition. International Journal of Engineering \& Technology (UAE), 7(3.2), 265-268.

http://dx.doi.org/10.14419/ijet.v7i3.2.14417

5. Nesterenko, M., Maslov, A. \& Salenko, J. (2018). Investigation of vibration machine interaction with compacted concrete mixture. International Journal of Engineering \& Technology (UAE), 7(3.2), 260-264.

http://dx.doi.org/10.14419/ijet.v7i3.2.14416.

6. Shigeyuki, D., Goryozono, Y. \& Hashimoto, S. (2012). Study on consolidation of concrete with vibration. Physics Procedia, 25, 325-332.

https://doi.org/10.1016/j.phpro.2012.03.091

7. Nesterenko, M.P. (2017). Progressive development of vibration installations with spatial vibrations for the formation of reinforced concrete products. Academic journal. Series: Industrial Machine Building, Civil Engineering, 2 (44), 16-23.

8. Svidersky, A.T. \& Delembovsky, M.M. (2010). Criteria for assessing the quality of vibrating platforms. Construction Engineering, 24, 24-27.

9. Sivko, V.Y. \& Kuzminets, M.P. (2012). Assessment of the influence of the working environment on vibration modes of vibrating machines. Construction Theory and Practice, 10, 3-5.

10. Nesterenko, M.P., Biletsky, V.S. \& Semko, O.V. (2017). Assessment of structural and technological parameters and performance of vibrating machines for the formation of reinforced concrete products. Academic journal. Series: Industrial Machine Building, Civil Engineering, 1 (43), 231-237.

11. Nazarenko, I.I. \& Nesterenko, M.P. (2015). Research methodology of the general dynamic model «technological machine for construction industry - processed environment». Construction Engineering, 34, 4-11. 